\title{
BMI and Association with Histopathological Characteristics of the Tumor in Postmenopausal Women
}

\author{
Pr Selma Sakhri* \\ Department of Medical Oncology, Chu Tizi Ouzou Hospital, Algeria
}

*Corresponding author: Pr Selma Sakhri, Department of Medical Oncology, Chu Tizi Ouzou Hospital, Algeria.

Received Date: February 24, 2019

Published Date: March 08, 2019

\section{Research Protocol}

The purpose of our study is to analyze the association between the increased bodyweight, by using the body mass index (BMI), and the histopathology of breast cancer (size of tumor, grade, hormone receptors, her2, lymph nodes) in postmenopausal women. In this retrospective study, 99 patients were examined, who were operated in our clinic who suffer from breast cancer from 12/2012 to $12 / 2014$. ER and PR tumors were categorized as positive if $1 \%$ of the nuclei was stained. HER2 tumors were categorized as positive if $>10 \%$ of the nuclei was stained. The patients were categorized as being normal weight with $\mathrm{BMI}<24,9 \mathrm{Kg} / \mathrm{m}^{2}$, overweight with $\mathrm{BMI}$ $25-29,9 \mathrm{Kg} / \mathrm{m}^{2}$, or obese with BMI $30 \mathrm{Kg} / \mathrm{m}^{2}$. The average of BMI was $28,28 \mathrm{~kg} / \mathrm{m}^{2}$ (range $18,64-44,76$ ). In the category of normal weight patients $\left(\mathrm{BMI}=24,9 \mathrm{Kg} / \mathrm{m}^{2}\right)$, we diagnosed 10 patients of stage I (25\%), 18 patients of stage II (45\%), and 12 of stage III (30\%). As far as tumor size concerns, 11 patients were in $\mathrm{T}_{1}$ $(27,5 \%), 9$ were in $\mathrm{T}_{2}(22,5 \%)$ and 5 in $\mathrm{T}_{3}(12,5 \%)$ stage. Regarding the lymph nodes, 20 patients were diagnosed in $\mathrm{N}_{0}$ (50\%), 14 in $\mathrm{N}_{1}(35 \%), 5$ in $\mathrm{N}_{2}(12,5 \%)$ and 2 in $\mathrm{N}_{3}$ (5\%). Referring to the hormone receptors and the expression of Her2, the most common combination was $\mathrm{ER}+\mathrm{PR}+\mathrm{Her} 2-$ in 26 patients $(65 \%)$, followed by $\mathrm{ER}+\mathrm{PR}+\mathrm{Her} 2+$ in 4 (10\%), ER-PR-Her2+ in 3(7,5\%) and ER-PRHer2- in 2 (5\%). In the category of overweight patients (BMI 25$29,9 \mathrm{~kg} / \mathrm{m} 2)$ we diagnosed 5 of stage I (18,5\%), 10 (37\%) of stage II, and $12(44,4 \%)$ of stage III. Concerning the tumor size, we had 13 patients in $\mathrm{T}_{1}$ stage $(48,14 \%), 9$ in $\mathrm{T}_{2}(33,33 \%)$ and 5 in $\mathrm{T}_{3}(18,5 \%)$. As far as lymph nodes concerns, 13 patients were diagnosed in $\mathrm{N}_{0}$ (48,14\%), 5 in $\mathrm{N}_{1}(18,5 \%), 3$ in $\mathrm{N}_{2}(11,11 \%)$ and 5 in $\mathrm{N}_{3}(18,5 \%)$. Referring to the hormone receptors and the expression of Her2, the most common combination was ER+PR+Her2- in 15 patients (55,55\%), ER+PR+Her2+ in 4 (14,8\%), ER-PR-Her2+ in 3 (11,11\%) and ER-PR-Her2- in 1 (3,7\%).In the category of obese patients (BMI $30 \mathrm{Kg} / \mathrm{m} 2$ ) the grade was: 9 patients in stage I (34,6\%), 9 in stage II $(34,6 \%)$ and 8 in stage III $(30,7 \%)$. Referring to the tumor size, we had 9 patients in $\mathrm{T}_{1}(34,6 \%), 15$ in $\mathrm{T}_{2}(57,7 \%)$ and 3 in $\mathrm{T}_{3}(11,11 \%)$. Respecting the lymph nodes 15 patients were in $\mathrm{N}_{0}$ $(57,7 \%)$.

In our study, we demonstrate that in postmenopausal women with BMI 25 we diagnosed larger tumors, more positive lymph nodes and higher grade of breast cancer, which indicates more aggressive growth and characteristics of the cancer cells. These tumors have high expression of $\mathrm{ER}+\mathrm{PR}+$ and low expression of Her2 +.

Acknowledgment

None.

\section{Conflict of Interest}

No conflict of interest. 